\title{
O PAPEL DA FONOLOGIA DO PORTUGUẾS BRASILEIRO NA TRADUÇÃO DE TEXTOS MUSICAIS
}

\author{
THE ROLE OF THE BRAZILIAN PORTUGUESE PHONOLOGY \\ IN THE TRANSLATION OF SINGABLE LYRICS
}

\author{
Graziela Pigatto Bohn | Lattes | grazielabohn@gmail.com \\ Universidade Católica de Santos
}

Roseane Silva da Cruz | Lattes | roseanescruz@gmail.com Universidade Católica de Santos

\begin{abstract}
Resumo: Este estudo investiga o processo tradutológico de músicas para o canto, verificando quais estratégias o versionista lança mão para que a tradução seja tanto logocêntrica como melocêntrica quando comparada à canção original. Para esse fim, fizemos uma comparação entre a notação musical da versão original da música Seasons of Love, composta por Jonathan Larson para o teatro musical Rent em 1994, e sua versão para o português brasileiro, realizada pela versionista Mariana Elisabetsky em 2016. Com base nos aspectos da fonologia do português brasileiro, em especial ritmo, acento e os processos de juntura segmental (COLLISCHONN, 2001), nos conceitos de acento métrico e ritmo sob a perspectiva da música (BENNETT, 1987; LACERDA, 1967), e nos processos tradutológicos de músicas para o canto (FRAZON, 2008), nossa análise mostra que não é possível a realização de uma tradução literal de músicas para o canto, o que leva o versionista a criar uma adaptação para que a letra traduzida possa ser acompanhada junto à notação musical de sua letra original e, ao mesmo tempo, não cause estranhamento ao ouvinte.
\end{abstract}

Palavras-chave: Versionista; Tradução de música para o canto; Português brasileiro; Notação musical; Teatro musical.

\begin{abstract}
This paper aims to investigate the translation process of singable lyrics, verifying which strategies the translator uses so the translated song remains both logocentric and melocentric when compared to the original. For this purpose, we compared the original sheet music of the song "Seasons of Love" by Jonathan Larson, from the musical "Rent" in 1994, with its Brazilian Portuguese translation by Mariana Elisabetsky, in 2016. On the
\end{abstract}


basis of the aspects of Brazilian Portuguese phonology, in particular rhythm, stress and the processes of segmental junction (COLLISCHONN, 2001), in the concepts of metric accent and rhythm from the music perspective (BENNETT, 1987; LACERDA 1967), and with the translation process of singable lyrics (FRAZON, 2008), we could see that the literal translation of a song is not possible when its intention is to be sung. Therefore, the translator needs to adjust the translated song in order to fit its lyrics into the melody, so the translated song can be naturally sung along with its original sheet music.

Keywords: Translator; Singable translation; Brazilian Portuguese; Sheet music; Musical theatre.

\section{Introdução}

Nos últimos anos, o ramo cultural do teatro musical no Brasil tem se expandido e importado cada vez mais montagens musicais renomadas de outros países, em especial dos teatros da Broadway (Broadway Theater) ou dos teatros da West End de Londres, dois dos mais representativos teatros de musicais em língua inglesa. As montagens brasileiras desses musicais exigem adaptações que transmitam a mesma informação agregada à montagem original em língua estrangeira. Por esse motivo, o versionista exerce um papel fundamental no processo de tradução de peças musicais, pois, no teatro musical, a história é contada, principalmente, por meio das canções. O versionista deve ainda preocupar-se em manter o mesmo esquema de rimas, repetições e estrofes, uma vez que a música original e a tradução estão submissas à mesma notação musical.

Neste estudo, buscamos analisar de que forma aspectos fonológicos da língua de chegada podem servir como uma ferramenta para que a canção versionada corresponda melocentricamente à canção original preservando o seu conteúdo.

Na primeira seção, trataremos dos aspectos que a tradução de músicas deve apresentar para que esta seja considerada cantável, de acordo com Frazon (2008). Na segunda seção, abordaremos os pontos teóricos musicais mais relevantes para o processo tradutológico de canções. Na terceira seção, discutiremos os aspectos fonológicos do português brasileiro, geralmente usados como ferramenta no trabalho do versionista. Na quarta seção, por meio da análise da versão brasileira da canção Seasons of Love, traduzida como "Dias de Amor" do teatro musical Rent, apresentamos nossos resultados, que são seguidos pelas considerações finais. 


\section{A tradução de textos musicais para o canto}

O termo texto musical refere-se à letra de canções. Todo texto musical traduzido para o canto é chamado de versão musical, e esse tipo de tradução é comissionado a profissionais versionistas, que são geralmente compositores, cantores, especialistas em óperas e dramaturgos. Uma vez que essa área requer conhecimentos teóricos musicais, são poucos os profissionais de tradução que atuam nesse campo.

Uma das tarefas do versionista é a de buscar soluções na língua de chegada para que a letra e a melodia se encaixem precisamente sem que haja a necessidade de alterar a partitura do texto musical, pois a tradução dos textos musicais está submissa à notação musical da canção original.

Segundo Frazon (2008, p. 391), a tradução de canções passa por um processo músico-textual que envolve três camadas de cantabilidade (the three layers of singability), cada uma das quais representando a finalidade que essa tradução deve atingir para que o texto musical seja considerado cantável.

A primeira camada é onde ocorre a combinação prosódica. De acordo com Frazon (p. 393), essa é a camada de maior relevância para a cantabilidade do texto musical traduzido, pois nela se realiza a correspondência métrica da canção. É a camada que torna o texto musical cantável, ainda que, neste estágio, a letra possa não fazer sentido. Por exemplo, na partitura na Figura 1, abaixo, os símbolos que representam as notas musicais e as palavras correspondem-se silabicamente, ao mesmo tempo que as tônicas das palavras devem corresponder aos tempos fortes da música, conforme Figura 2. Dessa correspondência dá-se a combinação prosódica, sendo possível acompanhar, simultaneamente, o texto musical original e traduzido sob a mesma notação musical (FRAZON, 2008, p. 393), conforme ilustramos a seguir:

Figura 1. Correspondência silábica

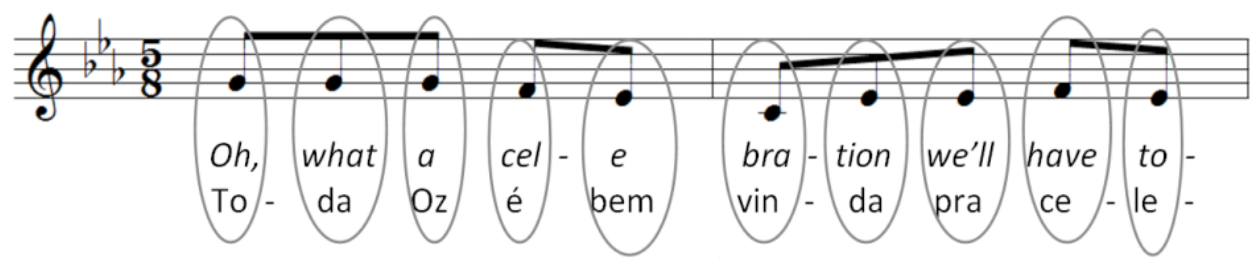

Fonte: elaborada pelas autoras. 
Figura 2. Correspondência tônica e tempos fortes

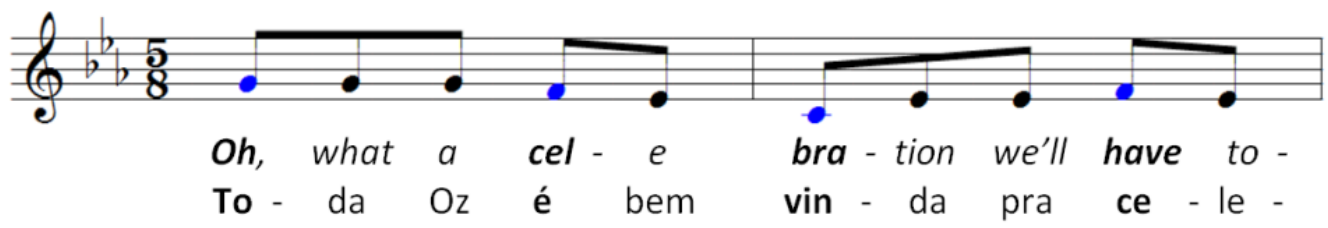

Fonte: elaborada pelas autoras.

$\mathrm{Na}$ segunda camada, temos a combinação poética, que diz respeito aos recursos estilísticos da poesia, mas que, sozinha, não torna o texto musical cantável, o que faz com que a segunda camada seja dependente da combinação prosódica presente na primeira camada. Por exemplo, no Quadro 1, a seguir, podemos perceber que a terceira coluna é logocêntrica, pois foca na tradução literal de palavras e falha ao estabelecer correspondência com os aspectos métricos da canção original. ${ }^{1}$

Quadro 1. Letra português / inglês de "Popular" de Wicked

\begin{tabular}{|c|c|c|}
\hline ORIGINAL & VERSÃO PARA O CANTO & TRADUÇÃO LITERAL \\
\hline $\begin{array}{l}\text { Popular, } \\
\text { you're gonna be popular! } \\
\text { I'll teach you } \\
\text { The proper ploys } \\
\text { When you talk to boys } \\
\text { Little ways } \\
\text { To flirt and flounce }\end{array}$ & $\begin{array}{l}\text { Popular, } \\
\text { te ensino a ser } \\
\text { popular } \\
\text { Uns truques } \\
\text { de quem testou } \\
\text { E se aprimorou } \\
\text { Estratégias } \\
\text { pra flertar }\end{array}$ & $\begin{array}{l}\text { Popular, } \\
\text { você será popular! } \\
\text { Eu vou te ensinar } \\
\text { Os truques certos } \\
\text { Para falar com os garotos } \\
\text { Pequenas maneiras } \\
\text { De flertar e se movimentar }\end{array}$ \\
\hline
\end{tabular}

Fonte: elaborada pelas autoras.

Na terceira camada, temos a combinação semântica, que diz respeito ao modo como as palavras relacionam-se mediante rimas, repetições e estrofes, e os efeitos de sentido que elas criam por meio da oralidade, manipulando as emoções do público. Frazon (2008, p. 392) nos diz que a combinação semântica é atingida quando o clímax melódico coincide com o clímax imposto no texto musical, dando significado à canção, isto é, letras felizes devem ser acompanhadas por uma melodia alegre, assim como às letras tristes são atribuídas melodias melancólicas; o texto musical reflete, portanto, o movimento que a música expressa.

\footnotetext{
${ }^{1}$ É comum que o idioma do texto musical original e do texto musical traduzido possuam divergências tanto sintáticas como fonológicas, levando o versionista a produzir uma adequação contextual na qual a informação é mantida, porém não é possível uma comparação tradutológica palavra por palavra entre os textos. A fim de justificar as escolhas tradutórias do versionista, Frazon (2008) refere-se à tradução de textos musicais cantáveis como adaptações.
} 
O versionista deve preocupar-se, ainda, com que o texto musical apresente uma tradução persuasiva e expressiva, sendo ela o efeito das atribuições devidas dos seus valores prosódicos e poéticos. A tradução do texto musical para o canto cumpre com suas exigências quando há a combinação semântica, pois a terceira camada é o produto final da junção das duas camadas anteriores.

\section{Elementos formais da música}

Vimos, na seção anterior, que, conforme Frazon (2008), o versionista deve cumprir algumas exigências a fim de que a tradução dos textos musicais seja cantável. A combinação prosódica é o primeiro item para que se atinja a cantabilidade, pois a partir dessa combinação é que obtemos a correspondência entre a sílaba e a notação musical, correspondência métrica entre a tônica da palavra e os tempos fortes da música; e é por meio dessa combinação, também, que o ritmo e a entonação da canção tornam-se perceptíveis.

Nesta seção, trataremos de alguns dos aspectos teóricos musicais - notação musical, acento métrico e ritmo - que o versionista deve levar em conta para que a tradução da música em questão seja apta ao canto.

\section{Notação musical}

No processo de tradução de textos musicais há um sistema musical textual que o versionista deve seguir para que a tradução do texto seja apropriada ao canto (FRAZON, 2008, p. 393). Uma das etapas é a correspondência silábica, de acordo com a qual cada sílaba cantada deve coincidir com uma notação musical. Segundo Bennett (1987), a notação musical é a representação do som por meio de símbolos, sendo alguns deles os que apresentamos nas Figuras $3-8$, abaixo:

Figura 3. Pauta ou pentagrama

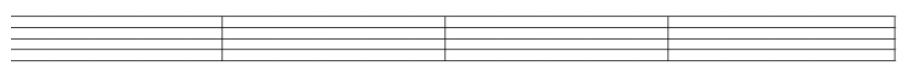

Fonte: Bennett (1987, p. 11, adaptada).

Figura 4. Claves

$$
\text { Clave de sol } \oint \text {, de dó } \mid \mathfrak{Y} \text { e de fá } \bigcirc:
$$

Fonte: Bennett (1987, p. 10, adaptada). 
A clave (Figura 4), dependendo de sua posição na pauta, é a que determina o nome das notas: dó, ré, mi, fá, sol, lá, si.

Figura 5. Notas e suas respectivas pausas

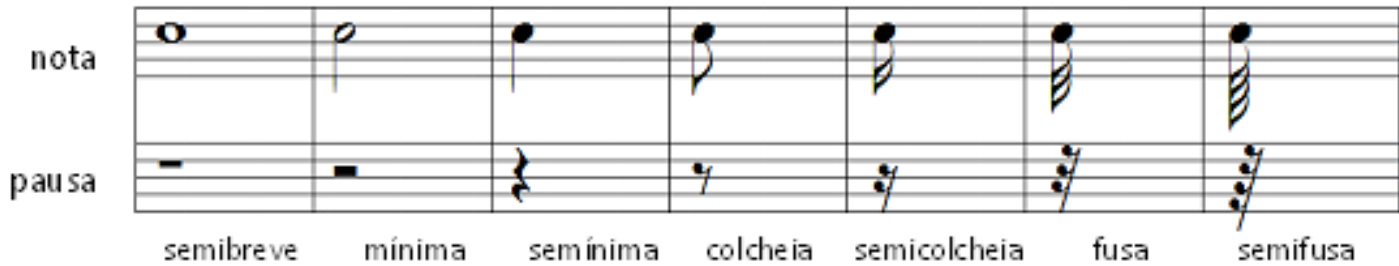

Fonte: Bennett (1987, p. 11 , adaptada).

As figuras de notas e pausas, dependendo de seu formato, têm a duração longa ou curta em relação à outra. A figura de semibreve, por exemplo, é a que possui o maior tempo de duração e abrange todas as demais:

Figura 6. Valor relativo das notas

1 semibreve
$=$
2 mínimas
$=$
4 semínimas
$=$
8 colcheias
$=$
16 semicolcheias
$=$
32 fusas

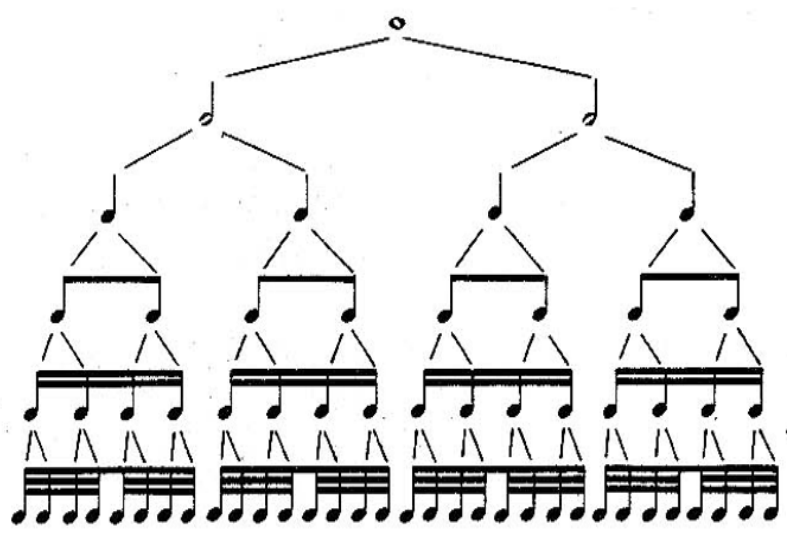

Fonte: Bennett (1987, p. 12).

Quando juntas no mesmo compasso, colcheias, semicolcheias, fusas e semifusas, podem apresentar o seguinte formato:

Figura 7. Colcheia e semicolcheia

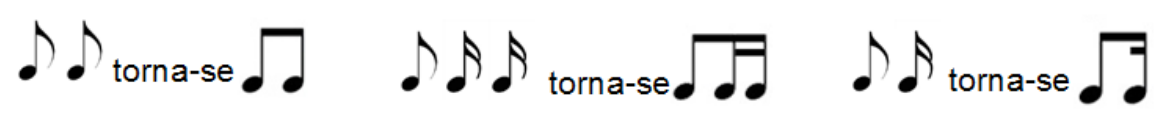

Fonte: Bennett (1987, p. 12). 
Para um som prolongado, quando as notas são da mesma altura, usa-se a ligadura de prolongamento (Figura 8), que faz com que a duração do som seja a soma da duração das notas ligadas; ou o ponto de aumento (Figura 9), que adiciona à nota metade do seu valor. Quando as notas ligadas são de alturas diferentes usa-se uma ligadura de expressão (Figura 10), a qual não altera o tempo de duração das notas.

Figura 8. Ligadura de prolongamento

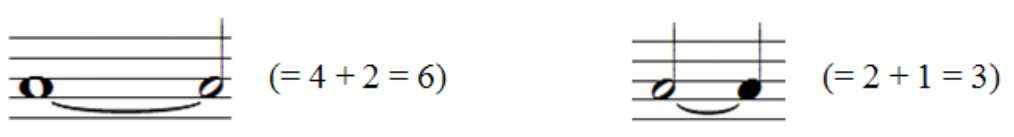

Fonte: Bennett (1987, p. 12 , adaptada).

Figura 9. Ponto de aumento

$$
\mathbf{o} \cdot \mathbf{0}+\delta(4+2=6)
$$

Fonte: Bennett (1987, p. 12).

Figura 10. Ligadura de expressão

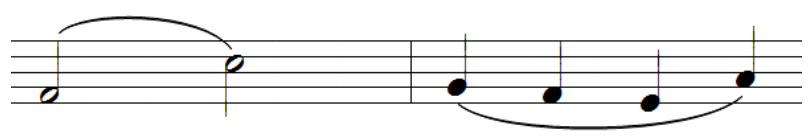

Fonte: Bennett (1987, p. 12 , adaptada).

A ligadura de prolongamento influencia os textos musicais, pois as notas ligadas, geralmente, são marcadas como uma só, ou seja, notas ligadas, preferencialmente, devem ser associadas a uma única sílaba.

\section{Acento métrico}

Namúsica, oacento métrico é definidoa partir dostempos fortes e fracos do compasso (LACERDA, 1987). O tipo de compasso pode ser identificado no início da partitura e é representado por uma fração chamada de fórmula de compasso. Nessa fração, o numerador indica a quantidade de tempos de cada compasso e o denominador indica a nota que terá a duração de 1 tempo (BENNETT,1987, p. 13): 
Figura 11. Fórmula de compasso
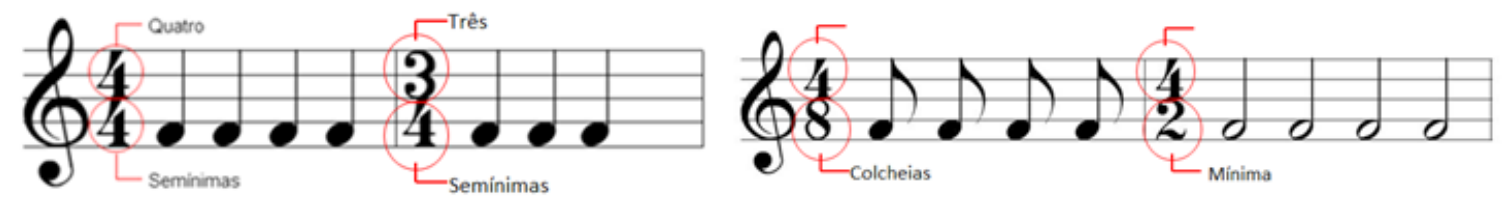

Fonte: Bennett (1987, p. 13 , adaptada).

Normalmente, o tempo forte $(f)$ é o primeiro tempo de cada compasso, sendo os tempos restantes denominados meio-forte $(m f)$ ou fraco $(p)$ (LACERDA, 1967, p. 1516), Vejamos alguns exemplos:

Figura 12. Compasso binário simples

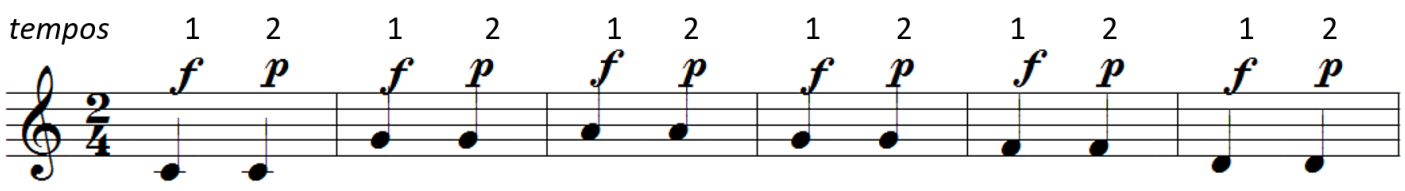

Figura 13. Compasso quaternário simples

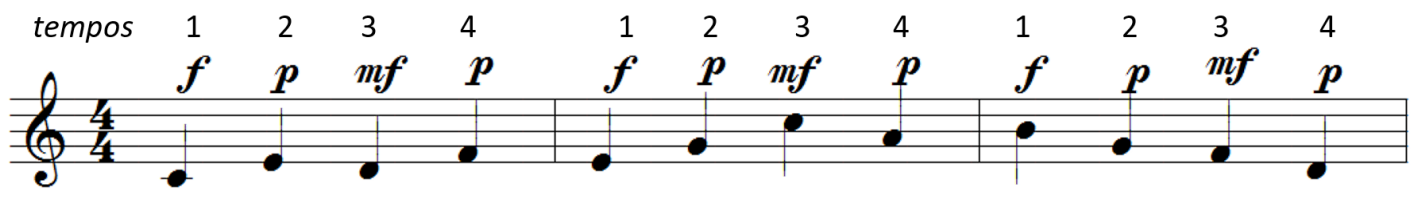

Fonte: Lacerda (1967, p. 15-16, adaptada).

Na composição, há recursos que podem ser usados para destacar certos pontos da música. Um desses recursos é a síncopa ${ }^{2}$, que ocorre quando há a presença da ligadura de prolongamento (LACERDA, 1967, p. 38). O tempo fraco da música é ligado ao tempo forte seguinte, criando um deslocamento da acentuação.

Figura 14. Síncopa

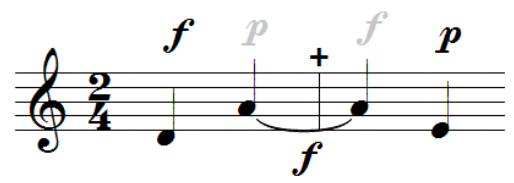

\footnotetext{
${ }^{2} \mathrm{Na}$ linguagem musical, o termo é usado no gênero feminino.
} 
Fonte: Lacerda (1967, p. 38 , adaptada).

Assim, podemos perceber que o acento métrico é definido a partir das batidas padrões fortes ou fracas da música e segue um parâmetro que raramente pode ser alterado. Para que o texto musical traduzido seja cantável, além da correspondência silábica, os tempos forte e meio-forte da música devem, preferencialmente, coincidir com a sílaba tônica das palavras (FRAZON, 2008, p. 393).

\section{Ritmo}

Enquanto a métrica pode ser definida pelos tempos fortes e fracos da música, o ritmo está relacionado à duração; ou seja, de acordo com Med (1984), as combinações entre as diferentes possibilidades de duração do som e silêncio - notas e pausas, organizados em proporções exatas - resulta no ritmo musical, sendo essa combinação responsável pela criação e caracterização de diferentes melodias.

Para Benward \& Saker (2009), ritmo e métrica operam em conjunto, sendo o ritmo um modelo de durações irregulares, enquanto que a métrica é formada por batimentos e medidas padrões:

Figura 15. Métrica e ritmo

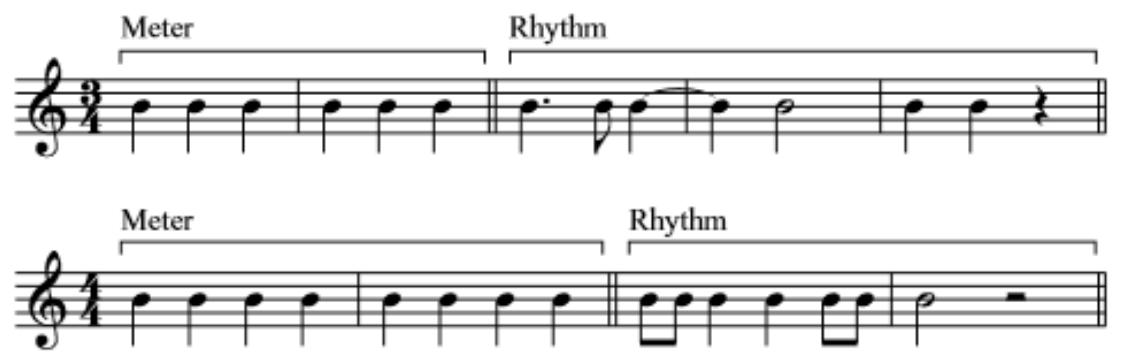

Fonte: Benward e Saker (2008, p. XVI).

Vale notar a contribuição de Hasty (1997, p. 4) no que diz respeito ao ritmo e à métrica. Segundo o autor, a métrica é fixa, e o ritmo é livre, uma vez que a métrica é uma medida padrão determinada e o ritmo é o movimento musical, influenciado pelos sentimentos e emoções do compositor e pela forma de expressão e execução do intérprete.

Medeiros (2009) justifica que o movimento da música é marcado pela melodia e as durações são seus organizadores, isto é, ainda que uma música seja reproduzida em uma velocidade diferente, as proporções das durações que a caracterizam são mantidas mentalmente de modo que a música executada seja reconhecida pelo ouvinte. Por essa razão, 
um dos métodos utilizados, por exemplo, é a atribuição de duas ou mais notas ligadas para sílabas longas, ou em final de frases para a criação de um ritmo melódico, uma vez que a música e a articulação das palavras cantadas são interdependentes.

\section{Propriedades fonológicas do português brasileiro}

Nesta seção, serão abordadas algumas propriedades fonológicas do português brasileiro a fim de entendermos como o versionista pode lançar mão de processos para fazer a correspondência entre letra e música. São elas: ritmo, acento e processo de juntura.

\section{Ritmo}

Para Medeiros (2009), o vínculo entre o ritmo musical e o ritmo linguístico é que em ambos o ritmo é um processo mental gerado a partir das práticas de movimentos longos ou curtos que apresentem uma padronização.

No ponto de vista linguístico, o ritmo é marcado pelas batidas da fala e suas proeminências. Essas proeminências determinam o acento das palavras: uma sílaba mais proeminente é denominada sílaba tônica, e uma sílaba menos proeminente é denominada sílaba átona (COLLISCHONN, 2001). O ritmo da fala é, também, marcado pela divisão do tempo em partes iguais, chamada de isocronia. Por meio da isocronia, línguas como o inglês, o russo e o português europeu são denominadas línguas de ritmo acentual, enquanto línguas como o francês, o japonês e o espanhol, línguas de ritmo silábico (MIGLIORINI; MASSINI-CAGLIARI, 2010).

O ritmo acentual, em (1), abaixo, é definido pela duração, sendo as sílabas tônicas longas e as sílabas átonas reduzidas. Essa duração, contudo, é dependente do tamanho do constituinte: quanto maior a palavra, menor a duração de cada sílaba, quanto menor a palavra, maior a duração. Já o ritmo silábico, em (2), abaixo, é definido pela intensidade: as sílabas tônicas são fortes e as sílabas átonas fracas, tendo cada sílaba, no geral, o mesmo tempo de duração (CAGLIARI, 2012, p. 41).

$\begin{array}{lll}\text { (1) Cats } & \text { chase mice } & 3 \text { sílabas } / 3 \text { tempos } \\ \text { The cats } & =4 \text { sílabas } / 3 \text { tempos } \\ \text { The cats } & =5 \text { sílabas } / 3 \text { tempos } \\ \text { The cats will chase the mice } \text { mice } & =6 \text { sílabas } / 3 \text { tempos } \\ \text { The cats will have chased the mice } & =7 \text { sílabas } / 3 \text { tempos }\end{array}$


(2)

Gatos perseguem ratos
Os gatos perseguem ratos
Os gatos perseguem os ratos
Os gatos perseguirão os ratos
Os gatos terão perseguido os ratos

$$
\begin{aligned}
& =\quad 7 \text { sílabas } / 7 \text { tempos } \\
& =\quad 8 \text { sílabas } / 8 \text { tempos } \\
& =\quad 9 \text { sílabas } / 9 \text { tempos } \\
& =\quad 10 \text { sílabas } / 10 \text { tempos } \\
& =\quad 12 \text { sílabas } / 12 \text { tempos }
\end{aligned}
$$

O ritmo do português brasileiro não possui, ainda, uma definição muito clara se é acentual ou silábico. Entretanto, Migliorini \& Massini-Cagliari (2010) e Cagliari (2012) argumentam que, apesar de as línguas serem divididas em dois grupos rítmicos, silábico e acentual, há imprecisões; categorizar uma língua como puramente silábica ou acentual não é possível, já que o ritmo é de caráter individual, idealizado na mente do falante (CAGLIARI, 2012).

\section{Acento}

No que diz respeito à fala, o acento está relacionado à proeminência relativa das sílabas que constituem as palavras. Embora existam exceções, há indícios acerca da regularidade no que diz respeito à acentuação tônica das palavras do PB: o acento é limitado às três últimas sílabas da palavra, o que as classifica em oxítonas - o acento cai na última sílaba (anZOL); paroxítonas - o acento cai na penúltima sílaba (ciDAde); e proparoxítonas - $\mathrm{o}$ acento cai na antepenúltima sílaba (PÂNtano).

Segundo Collischonn (2001), as oxítonas apresentam ainda duas classificações: oxítonas terminadas em consoantes e oxítonas terminadas em vogais, sendo as palavras terminadas em consoante mais frequentes em receber o acento oxítono do que aquelas que terminam com vogais (2001, p. 134). Isso porque a relação não está entre a palavra e o acento, mas, sim, entre a sílaba e o acento. $\mathrm{O}$ fato de a sílaba terminar em consoante a faz ser pesada, atraindo o acento (2001, p. 135):

(3) $\begin{array}{lll}\text { SUga } & \rightarrow & \text { suGAR } \\ \text { COlhe } & \rightarrow & \text { coLHER } \\ \text { MUla } & \rightarrow & \text { muLHER } \\ \text { ANjo } & \rightarrow & \text { anZOL }\end{array}$

$\mathrm{O}$ acento paroxítono é o mais natural para o falante nativo da língua. E, por ser a formação de paroxítonas a mais comum do PB, é normal que novas palavras introduzidas na língua respeitem esse padrão (COLLISCHONN, 2001, p. 133). 
(4) SANdwich $\rightarrow$ sanduÍche

FACEbook $\rightarrow$ faceBUki

CInema $\rightarrow$ ciNEma

Já as proparoxítonas são as menos frequentes, por tratar-se de um grupo formado a partir de palavras originárias do Latim e do Grego. É comum, ainda, sua modificação por meio de um processo de apagamento da penúltima sílaba, reclassificando-as em paroxítonas. Por exemplo, é natural aos falantes nativos do português brasileiro falar [' $\mathrm{j} i$. kra] em vez de ['Si.ka.ra] para 'xícara' e [a'bo.bra] em vez de [a'bo.bo.ra] para 'abóbora' (COLLISCHONN, 2001, p. 133). Para Collischonn, "o acento proparoxítono é marcado, no sentido de que é menos usual. É um acento especial, contrário à tendência geral de acentuar a penúltima sílaba." (COLLISCHONN, 2001 p. 133).

Um aspecto que também influencia a marcação de acento no PB é a junção de afixos à palavra. Por exemplo, o acréscimo de um sufixo derivacional em uma palavra fará com que a posição do acento seja alterada. Por outro lado, em casos de prefixo e sufixo flexional de número em nomes, a posição do acento, geralmente, permanecerá a mesma (COLLISCHONN, 2011, p. 136):

\section{(5) SUFIXO DERIVACIONAL}

FAca $>$ faCAda

ÁRvore > arvoREdo

poLÍcia $>$ policiAL

capitAL > capitaLISta

\section{SUFIXO FLEXIONAL}

FAca $>$ FAcas

ÁRvore > ÁRvores

poLÍcia $>$ poLÍciais

capiTAL > capiTAIS

\section{PREFIXO}

SOlo $>$ subsolo

inteliGENte $>$ superinteliGENte moDERno > ultramoDERno

CARga $>$ sobreCARga

Vale observar, nos exemplos em (5), acima, que, no caso dos sufixos derivacionais, a possibilidade de alteração do acento permite que as palavras ajustem-se à tendência de acentuação natural da língua: ÁRvore e capiTAL tornam-se proparoxítonas com o acréscimo do sufixo derivacional: arvoREdo e capitaLISta.

\section{Processos de juntura}

Além da marcação de acento da língua, interessam-nos também os processos fonológicos que afetam as cadeias de palavras do $\mathrm{PB}$, como os de juntura segmental, em especial aqueles que afetam os núcleos silábicos, resultando em ressilabação, podendo servir como ferramenta para que haja correspondência entre tempo musical e sílabas.

O primeiro processo que abordaremos aqui trata do apagamento da vogal átona /a/ em posição final de palavra, quando a vogal inicial da palavra seguinte não portar o acento 
da frase (BISOL, 1996, p. 160). O exemplo (6a), abaixo, traz uma ocorrência licenciada de elisão vocálica no $\mathrm{PB}$, enquanto que o exemplo (6b) nos mostra um caso em que a segunda vogal, destacada em maiúscula, porta o acento frasal e, por isso, não permite a elisão.

(6) a) compra uvas maduras $\rightarrow$ [com.pru.vas.ma.du.ras]

b) compra uvas $\rightarrow$ [com.pra.U.vas]

(BISOL, 1996, p. 160)

Para Bisol (1996), o apagamento da vogal /a/ evita o choque de picos silábicos, como no exemplo (6a): em "pra” /a/ foi desagregada da sílaba e as consoantes /p/ e /r/ agregaram-se à vogal inicial da palavra seguinte, criando uma nova sílaba.

Enquanto Bisol trata dos dialetos do Sul do país, Nogueira (2007, p. 53) defende que a elisão, no dialeto paulista, também afeta a vogal $[\mathrm{u}]$ em posição final quando a vogal seguinte não portar o acento da frase, como podemos observar no exemplo (7b). Enquanto em (7a) o processo atende as exigências para ser aplicado, em (7b) a vogal tônica /a/ em "água" carrega o acento frasal e impossibilita sua aplicação.
(7) a) aluno atento
$\rightarrow$ [a.lu.na.ten.to]
b) bebo água
$\rightarrow$ [be.b[u].Á.gua]

(NOGUEIRA, 2007, p. 53)

O segundo processo, a ditongação, ocorre quando a vogal final de uma palavra se une à vogal inicial da palavra seguinte, formando assim um ditongo; nessa formação não há nenhum apagamento, mas há a exigência de que uma das vogais seja alta, /i/ ou /u/, e átona (BISOL, 1996, p. 160):
(8) a) leque azul
$\rightarrow$ [le.kja.zul]
b) menina humilde
$\rightarrow$ [me.ni.naw.mil.de]

(NOGUEIRA, 2007, p. 80)

Por último, há a degeminação, que ocorre, segundo Bisol, quando, entre vocábulos há o encontro de duas vogais idênticas e átonas, resultando em uma fusão (1996, p. 160):
(9) a) menina alegre
$\rightarrow$ [me.ni.na.le.gre]
b) leque escuro
$\rightarrow$ [le.kis.cu.ro] 
Quanto à tradução de textos musicais, para Carmo Junior (2012), o texto a ser cantado deve respeitar, principalmente, as regras musicais e, por essa razão é comum o versionista lançar mão de processos fonológicos próprios das línguas de chegada, como por exemplo, a epêntese ou apagamento de segmentos e a mudança da posição do acento tônico.

\section{Análise do corpus}

Com base no que foi apresentado nas seções anteriores, nossa proposta neste estudo é investigar se, na prática, é possível que a canção traduzida seja cantada com a mesma notação musical da canção original respeitando ou não as propriedades de acento e de processos de juntura do $\mathrm{PB}$. Além disso, buscamos identificar se, no processo tradutológico, o versionista atingiu as exigências que tornam a tradução do texto musical apta ao canto. Para esse fim, e com o intuito de constatar a existência da prosódia músico-textual na tradução, analisaremos a versão do texto musical para o PB da música "Dias de Amor", do teatro musical Rent, tendo como base a partitura da canção original Seasons of Love.

Nas sessões seguintes serão analisadas as questões rítmicas musicais e suas relações com a fala - acento e processos de juntura - e a fidelidade ou não do tradutor quanto ao conteúdo do texto musical e quanto à notação musical da canção "Dias de Amor".

\section{Adaptação rítmica por processos de juntura}

Vimos anteriormente que, para que ocorra a correspondência nota/sílaba, o texto musical deve ser silabicamente dividido, e espera-se que cada sílaba seja atribuída a uma nota musical.

Com a partitura de Seasons of Love para o canto, podemos perceber que a métrica, determinada pela fórmula de compasso, é quaternária simples, ou seja, cada compasso é dividido em 4 tempos e a semínima será a nota com 1 tempo de duração:

Figura 16. Seasons of Love, introdução

\section{SEASONS OF LOVE}

from the Broadway Musical Rent

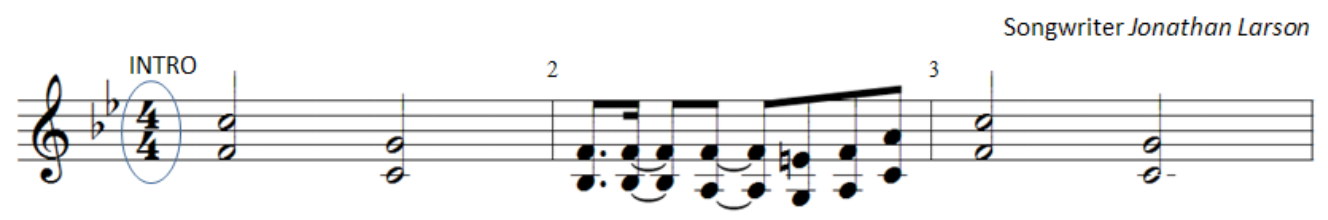

Fonte: elaborada pelas autoras. 
Pode-se fazer a distribuição dos tempos em notas e pausas de diversas maneiras, como por exemplo:

Figura 17. Distribuição dos tempos nos compassos

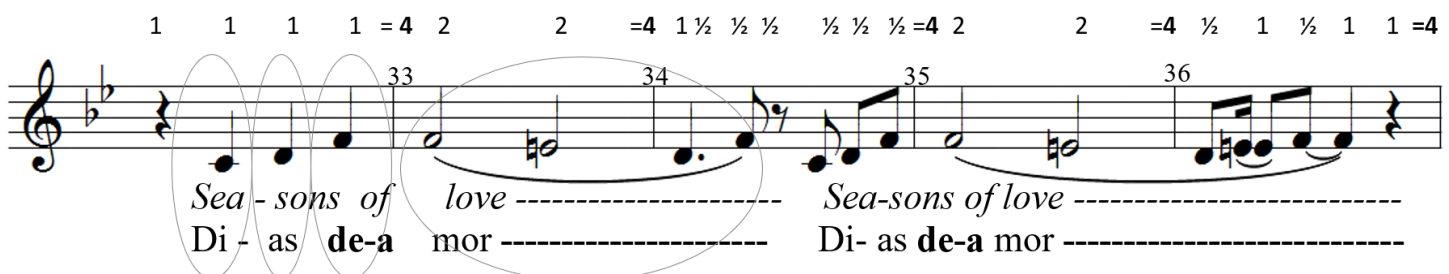

Fonte: elaborada pelas autoras.

Sabemos que a ligadura de prolongamento une as notas, somando seus valores e fazendo com que elas correspondam a uma única sílaba. Entretanto, no trecho destacado na Figura 17 acima, temos uma ligadura de expressão, pois as notas ligadas são de diferentes alturas. Apesar de as ligações dessas quatro notas, compasso 33-35 (Figura 17), indicarem quatro sílabas, notamos que o letrista tende a atribuir uma só sílaba às notas com ligadura de expressão. Dessa forma, podemos dizer que, nos compassos desse exemplo cabem, respectivamente: 3 sílabas, 1 sílaba, 3 sílabas e 1 sílaba.

No texto traduzido, podemos observar a frase "de amor", no qual a vogal final /e/ em 'de', realizada como [i] pelos falantes do PB, une-se à vogal inicial/a/ da palavra 'amor'. Isso indica que as fronteiras vocálicas passaram por um processo de ditongação, correspondendo, portanto, a uma única nota:

(10) de amor $\rightarrow \quad$ [dja.mor]

No compasso 30 há outro caso de ditongação:

Figura 18. Ditongação no compasso 30

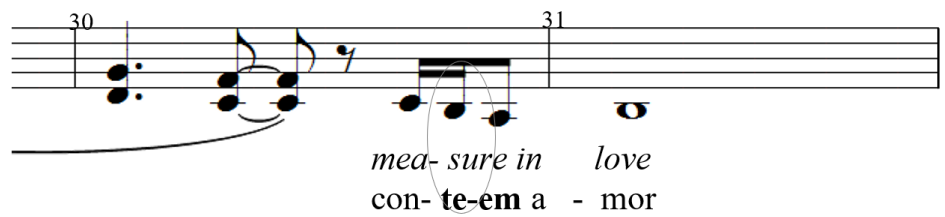


Neste caso a última vogal de "conte" [kõtfi] une-se ao [e] de 'em', formando uma única palavra de duas sílabas:

(11) conte em $\rightarrow \quad[$ kõ.tjẽ $]$

No trecho que segue, apresentamos outra ocorrência de ditongação que permite que a sílaba seja associada a uma única notação musical.

Figura 19. Ditongação no compasso 46

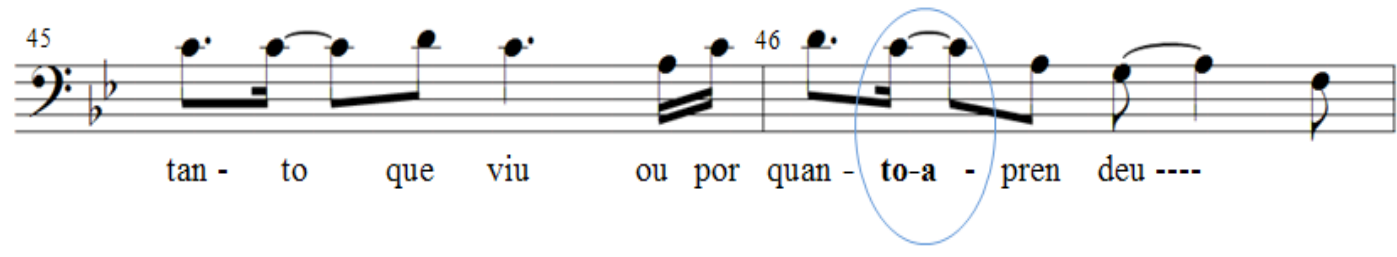

Fonte: elaborada pelas autoras.

Na palavra "quanto" a vogal átona /o/, realizada como [u], une-se à vogal inicial /a/ de "aprendeu". Temos, aí, portanto, um ditongo, que corresponde a uma única nota, resultado da junção da sílaba [to] com a vogal /a/.”

(12) quanto aprendeu $\rightarrow \quad$ [quan.twa.pren.deu]

Entretanto, para Nogueira (2007) e Santos (2007), no dialeto paulista a vogal átona $[\mathrm{u}]$, em posição final de palavra, também pode ser elidida, assim como o /a/ átono na regra de elisão para os dialetos do Sul proposta por Bisol (1996), desde que as outras condições sejam também respeitadas. Assim, segundo as autoras, podemos também dizer que o processo de juntura do trecho em questão poderia ser a elisão, conforme Figura 20, abaixo.

Figura 20. Elisão

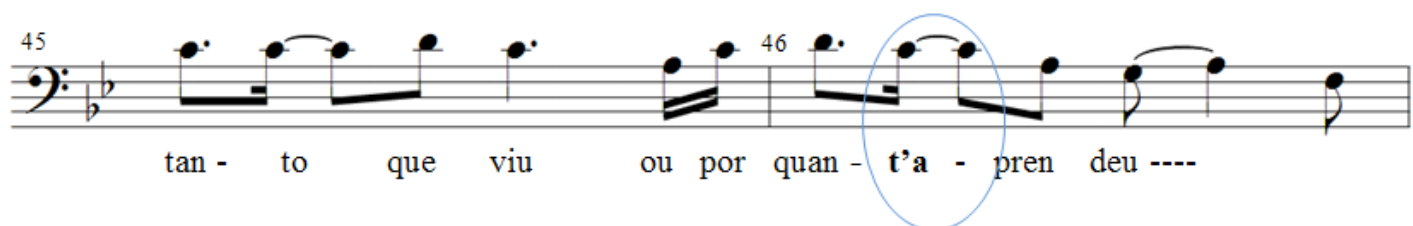

Fonte: elaborada pelas autoras. 
(13)

$$
\text { quanto aprendeu } \rightarrow \quad \text { [quan.ta.pren.deu] }
$$

Vemos, entretanto, que indiferentemente do processo aplicado, ditongação ou elisão, forma-se uma única sílaba.

No compasso 40, encontramos outra aplicação de processo de juntura que contribui para a associação da sílaba a uma única notação musical, como mostra a Figura 21:

Figura 21. Degeminação

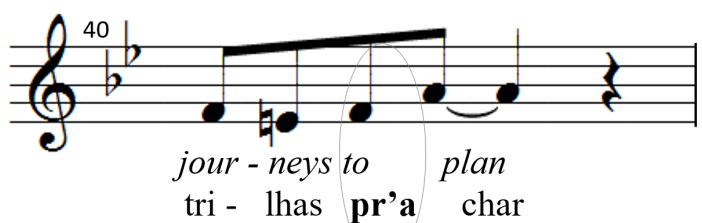

Fonte: elaborada pelas autoras.

Outro exemplo, encontrado no compasso 49, a seguir, além da silabação entre $m a[s \# a]$, formando a sílaba "sa", trata-se de um processo de ditongação para que uma correspondência entre sílaba e nota seja estabelecida:

Figura 22. Ressilabação com ditongação

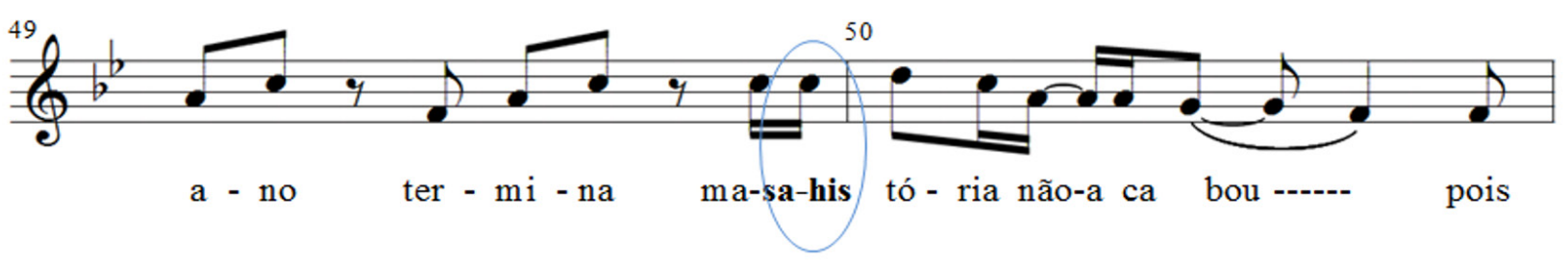

Fonte: elaborada pelas autoras.

$$
\text { mas a história } \rightarrow \quad \text { [ma.sais.tó.ria] }
$$

Percebemos, por meio das ocorrências apresentadas acima, que processos de juntura são, portanto, estratégias linguísticas a favor do versionista, pois, por meio desses processos, pode ser feita a correspondência nota/sílaba de modo que não haja alterações nos aspectos melocêntricos da canção original. 


\section{Adaptação rítmica por alteração do acento tônico}

Entendemos que o acento tônico é a proeminência da sílaba na fala, uma em relação à outra e, no $\mathrm{PB}$, o acento restringe-se às três últimas sílabas das palavras. Já na música, o acento métrico corresponde aos tempos fortes e fracos do compasso. No texto musical para o canto, é preferível que o acento tônico e os tempos fortes da música coincidam.

Como vimos anteriormente, a divisão métrica de Seasons of Love é quaternária simples (4/4), fórmula que define quais serão os tempos fortes e fracos da música e, unida ao trecho musical, pode ser representada dessa maneira:

Figura 23. Compasso 4/4, tempos forte e fraco em Seasons of Love

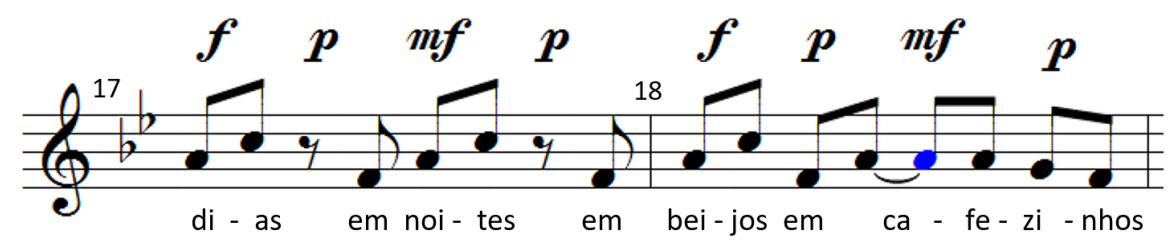

Fonte: elaborada pelas autoras.

A ligadura no compasso 18 indica uma síncopa, ou seja, ela desloca os acentos (Figura 23). Assim, essa nota que será tocada como uma só recebe o acento meio-forte.

Vejamos agora o acento tônico das palavras desses compassos:

DIas em NOItes, em BEIjos em cafeZInhos

Sabemos que as palavras 'dias', 'noites', 'beijos' e 'cafezinhos' são paroxítonas, pois o acento tônico cai na penúltima sílaba.

Na partitura, ao fazermos a correspondência entre o acento métrico e o acento tônico, obtemos o seguinte resultado:

Figura 24. Acento métrico e acento tônico

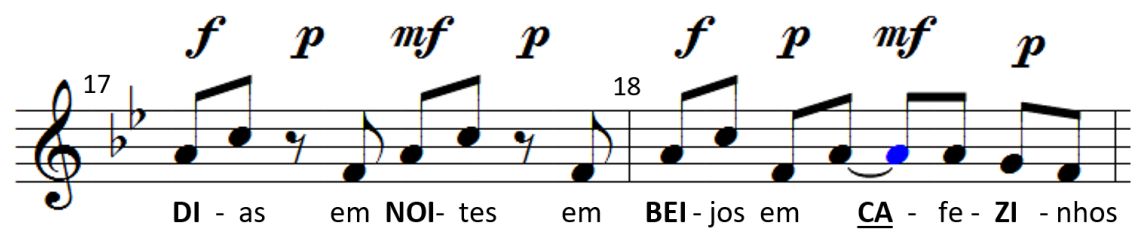

Fonte: elaborada pelas autoras. 
Podemos perceber que o acento tônico e os tempos fortes da música são correspondentes em DI, NOI e BEI, como esperado. Na palavra "cafezinho", porém, há um deslocamento do acento tônico de "caFÉ" para "CAfé” a fim de que corresponda ao tempo forte da música, sendo perceptível, ainda que menos intenso. Em versões musicais, a alteração do acento é comum, pois o texto musical traduzido está submisso à partitura do texto musical original, porém essa alteração deve ser o último recurso ao qual o versionista deve recorrer, pois, segundo Cagliari (2012, p. 29), quando a música cantada viola a estrutura da língua, pode causar estranheza para o ouvinte.

\section{Alteração da notação musical}

Vimos anteriormente que, na tradução do texto musical para o canto, o versionista deve dar importância às questões músico-textuais das canções e deve respeitar a notação musical da canção original, pois esta não deve ser alterada. Tais questões já foram previamente analisadas neste estudo.

Em "Dias de Amor", entretanto, encontramos casos de alterações na partitura, como mostra o trecho a seguir.

Figura 25. Ausência da nota

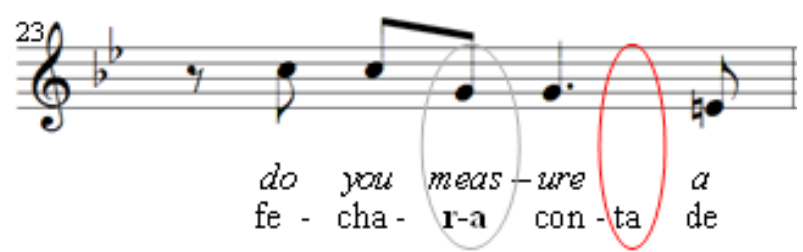

Fonte: elaborada pelas autoras.

Nesse compasso, é visível a ausência de uma nota que corresponda à sílaba “ta”. Para resolver essa falta de correspondência, a versionista precisou alterar a partitura original. O ponto de aumento do tempo da semínima, a nota que faz correspondência com a sílaba "con", foi transformado em colcheia, pois, teoricamente, ambos, nesse caso ponto e colcheia, possuem o mesmo valor de tempo de duração $\left(. .^{\prime}+{ }^{+} \downarrow\right)$, apresentando o seguinte resultado: 
Figura 26. Alteração da notação musical 1

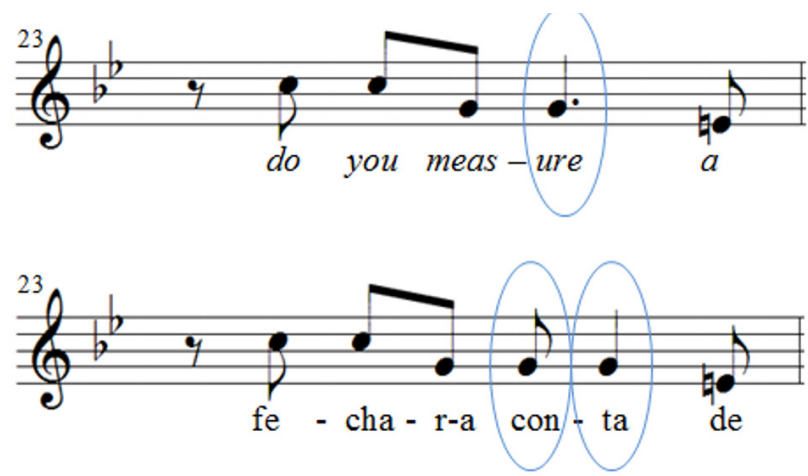

Fonte: elaborada pelas autoras.

Uma solução à vista disso seria o uso da expressão "prestar contas”, pois seria fiel à logocentria e, desse modo, excluiria a necessidade do uso do artigo "a”, reduzindo o número de sílabas de formar a haver coincidência com as notas musicais da partitura original:

Figura 27. Solução para a alteração da notação musical 1

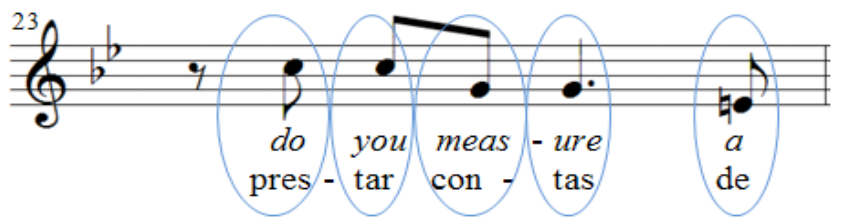

Fonte: elaborada pelas autoras.

Contudo, há casos em que a informação dada na música original não pode ser adaptada, muitas vezes por se tratar de uma expressão consagrada cuja alteração não teria boa aceitação do público; nestes casos, ao versionista não resta outra opção senão traduzir o texto musical literalmente. Em Seasons of Love, o verso inicial refere-se ao tempo em minutos contido em um ano, um fato que não pode ser alterado na tradução. Entretanto, ao analisarmos a correspondência silábica entre as expressões, temos:

five hun.dred twen.ty-five thous.and six hun.dred min.utes - 8 palavras 13 sílabas qui.nhen.to.se vin.te cin.co mil seis.cen.tos mi.nu.tos -7 palavras 15 sílabas

Silabicamente, a informação original e a traduzida não coincidem. Devido a isso, a tradução para o PB não encaixa na notação musical da canção original. Nesse caso, vemos 
que a versionista lança mão de uma modificação na notação musical para que, no canto, as palavras não causem estranheza ao ouvinte:

Figura 28. Alteração da notação musical 2
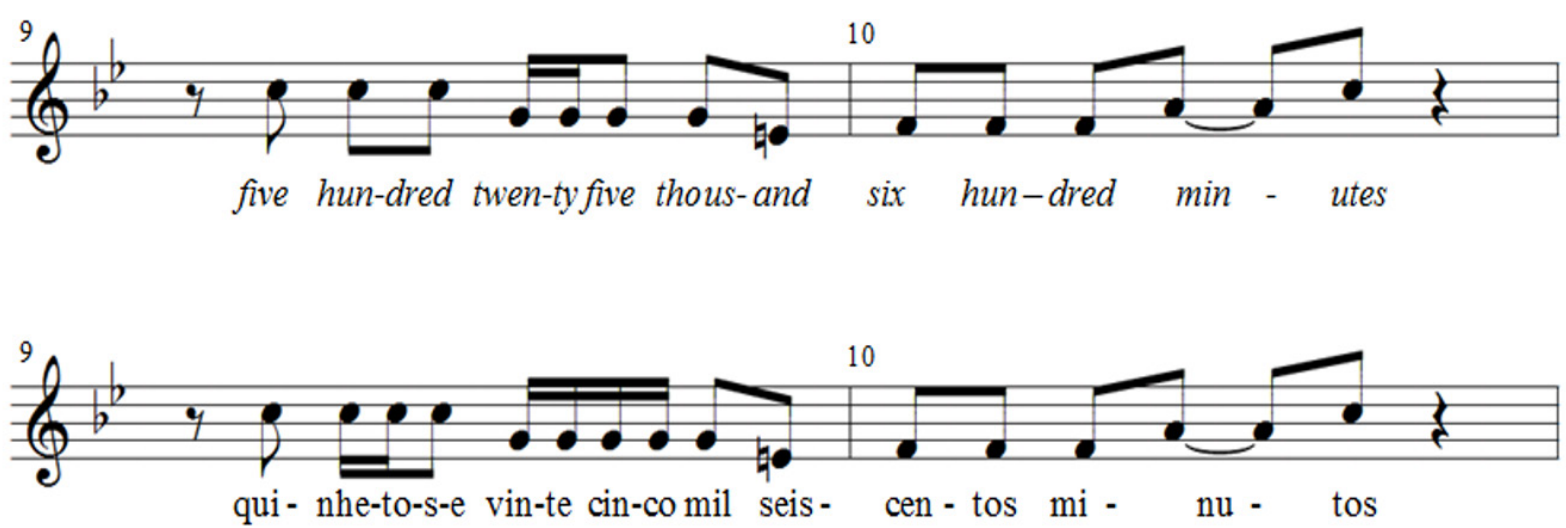

Fonte: elaborada pelas autoras.

O exemplo acima foi, portanto, uma exceção às regras da tradução de músicas para o canto, pois no conflito entre o logocêntrico e o melocêntrico, o literalismo foi de maior relevância para que informação fosse precisamente transmitida.

\section{Considerações finais}

O objetivo geral desta pesquisa foi analisar o processo tradutológico presente nas versões de músicas para o canto no teatro musical, averiguando de quais estratégias o versionista lança mão para que a tradução seja tanto logocêntrica como melocêntrica. Conforme Frazon (2008), a música traduzida cantável é aquela que atinge todos os níveis prosódicos músico-textuais, sendo eles a correspondência silábica, a correspondência entre o acento tônico e os tempos fortes da música, a combinação poética e a combinação semântica.

Com base nesses princípios, percebemos que a canção analisada cumpriu com as exigências que a tornam cantável: da mesma forma que a canção em PB pode ser acompanhada junto à melodia da canção em inglês, a música traduzida não interfere nos efeitos de sentido da música original. Porém, na partitura, que não deve ser alterada, foram encontradas duas mudanças quando a tradução precisou ser literal e não houve a possibilidade de uma adaptação.

Notamos também que aspectos da fonologia do $\mathrm{PB}$ podem ser uma ferramenta no trabalho do versionista. Tanto a alteração do acento tônico quanto processos de juntu- 
ra foram recursos utilizados para que houvesse a correspondência métrica entre texto e música, com o intuito de que o texto musical traduzido possa ser cantado juntamente à partitura original.

Desse modo, concluímos que o versionista tende a manter o melocentrismo da canção original e que suas traduções são adaptações que, embora com outras palavras, criem o mesmo efeito de sentido a fim de que a música original e a música traduzida soem como uma só.

\section{Referências}

BENNETT, R. Elementos Básicos da Música. Rio de Janeiro: Jorge Zahar Editor, 1987.

BENWARD, B.; SAKER, M. Music in Theory and Practice. 8. ed. New York: McGraw-Hill Education, 2009.v. 1.

BISOL, L. O Sândi e a Ressilabação. Letras de Hoje, Porto alegre, v. 31, n. 2, p. 159-168, jun. 1996.

CAGLIARI, L. C. Línguas de Ritmo Silábico. Revista de Estudos da Linguagem, Belo Horizonte, v. 20, n. 2, p. 23-58, jul./dez. 2012.

CARMO JÚNIOR, J. R. do. Sobre a Gramática da Palavra Cantada. Cadernos de Estudos Linguísticos, Campinas, v. 54, n. 2, p. 205-222, jul./dez. 2012.

CARVALHO JÚNIOR, A. D. de. Análise de padrões Musicais Rítmicos e Melódicos Utilizando o Algoritmo de Predição por Correspondência Parcial.92p. Dissertação (Mestrado em Sistemas de Computação) - Centro de Ciências Exatas e da Natureza, Universidade Federal da Paraíba, João Pessoa, 2011.

COLLISCHONN, G. O acento em Português. In: BISOL, L. Introdução a estudos de fonologia do português brasileiro. 3. ed. Porto Alegre: EDIPUCRS, 2001, p. 125-131.

FRAZON, J. Choices in Song Translation. The Translator, London, v. 14, n. 2, p. 373-399, out. 2008.

HASTY, C. F. Meter as Rhythm. New York: Oxford University Press, 1997.

LACERDA, O. Compêndio de Teoria Elementar da Música. 3. ed. São Paulo: Ricordi Brasileira, 1967.

LARSON, J. Rent. New York: Music Theatre International, 1994. 1 partitura, 8 p. Piano.

MED, B. Ritmo. 3. ed. Brasília: MusiMed, 1984.

MEDEIROS, B. R de. Ritmo na língua e na música: o elo possível. Música em Perspectiva, Curitiba, v. 2, n. 2, p. 45-63, out. 2009.

MIGLIORINI, L. M. de Q. MASSINI-CAGLIARI, G. Sobre o ritmo do português brasileiro: evidências de um padrão acentual. Revista Virtual de Estudos da Linguagem, São Paulo, v. 8, n. 15, p. 310-328, 2010. Disponível em: http://hdl.handle.net/11449/124843. Acesso em: 22 fev. 2017. 
NOGUEIRA, M. V. Aspectos Segmentais dos Processos de Sândi Vocálico Externo no Falar de São Paulo. 144 p. Dissertação (Mestrado em Linguística) - Departamento de Semiótica e Linguística Geral, Universidade de São Paulo, São Paulo, 2007.

SCHWARTZ, S. A New Musical Wicked. Minnesota: Hal Leonard, 2003. 2 partituras, 12 p. Piano/ Vocal.

TENANI, L.E. Domínios Prosódicos no Português. 377p. Tese (Doutorado em Linguística) - Instituto de Estudos da Linguagem, Universidade Estadual de Campinas, São Paulo, 2002.

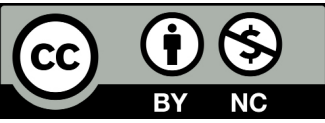

Data de submissão: 15/03/2018

Data de aceite: $19 / 11 / 2018$ 